\title{
Calcium concentrations in wetland groundwater in relation to water sources and soil conditions in the recharge area
}

\author{
P.P. Schot and M.J. Wassen \\ Department of Envommental Studics, Lxinerwty of Utredh, P.O. Box 80115, 3508 TC Utredh, \\ Nitherlands
}

\section{ABSTRACT}

Sichot, P.P. and Wassen, M.J., 1993. Calcium concentrakions in wetland groundwater in relation to water sourees and sol conditions in the recharge area. J. Hydrol., 141:197-217.

Over the past several decades. vegetation communities in lowland wetlands in Western Europe have changed. Species-rich, !ow-productivity (i.e. low primary bionass production) communities characteristic of rich fens (fens characterized by mitncrophilous spectes) have declined and are being replaced by vegetation communities characteristic of high-productivity rich fens, poor fens (fens characterized by ombrophilous species) and bogs. High concentrations of calcium in groundwater ate generally believed to $b^{*}$ an important controlling factor on the vegetation of rich fens Management for the protection of low-produtivity rich fens therefore generally aims at conservation of calcareous groundwater conditions in the rooi zone of lowland wellands.

This paper relates the occurrence of calcium-rich groundwater in hwhend wethands of the Central Netherlands to water sources and soil conditions in the groundwater recharge area. The chemical composition of the following groundwater lypes is compared: groundwater recharged at a sandy ridge adjacent to the wetland afea (ridge water), groundwater recharged by precipitation within the wetland (peat water); groundwater retharged by surftce water in the wetland Objective hydrological criteria are used to classify groundwater analyses itcording to recharge area. Oxygen-18 proved an essential criterion for the distinction between genetic groundwater types. It is therefore recommended to make oxyeen-18 analysis standard procedure in geohydrologieal wetland research. Calcium concentrations are generall, not suitable as tracers of different iypes of rechitge areas.

All grouncwater types contain calcium. In contrast io what is generally assumed, lowest concentrations are ohserved in ridge water. Higher calcium concentrations are found in groundwater recharged in wetlands, especially in intiltrated surface water. Nutrient concentrations in both ridge and peat water are low, whils those in infiltrated surface water are signiticanty higher.

The main condusion for nature conservation is that calctem-rich and mesotsophic conditions in the row zone ean be realised not only by the seepage of groundwater from upland sandy recharge areas, as is genterally thought, but also by the seepage of peat water. This is important as a severe deterforation in the quality of fidge water seening upward on the river plain may be anticipated in the near future, which forms a threat wo low-productivity rich fens. Peat water may offer an allernative water source for the conservation or regeneration of low-productivity rich fens.

Cotrespontence o: P P. Schot, IWACO Consultants for Water and Environment, P.O. Fox 5531, 3009 AM Roterdam. Notherlands. 
appears to be low (Waughman 1980, Wassen et al., 1990). Patrick (1974) and Kenmers (1986) ascribe an important role to the $\mathrm{Ca}^{2+}$-ion for phosphate availability to plants through precipitation of $\mathrm{Ca}-\mathrm{P}$ minerals. Wilson and Fitter (1984) suggested that micro-organisms decrease phosphatc availability through conversion of inorgatic-phosphorus to organic forms under calciumrich cunditions. However, it remains unclear whether phosphorus is the limiting factor in low-productivity rich fens, since many contradictory results have been published on the relation between phosphorus (and also nitrogen and potassium) contents in groundwater and soil and species composition along the rich len-poor fen-bog gradient (e.g. Waughman, 1980; Wilson and Fitter, 1984: Verhoeven and Arts, 1987; Verhoeven et. al.. 1988b; Succow, 1988; Koerselman et al., 1990).

Highest calcium concentrations are observed in infiltrated surface water. However, the concentrations of all nutrients are also significantly higher than those in ridge water and peat water, which mokes this type of water unsuitable for low-productivity rich fens. The upward seepage of ridge water and of peat water show nutrient concentrations which are statistically equal at a level of $P<0.01$. At a level of $P<0.05$, a higher ammonium concentration is observed in the secpage of the peat water. In contrast, however, calcium concentration is significantly higher in the upward seepage of peat water $(P<0.01)$, which may exert a limiting effect on phosphorus availability to plants.

The main conclusion for nature conservation is that calcium-rich and mesotrophic conditions in the root zone can be realised not only by the seepage of groundwater from upland sandy recharge areas, but also by the seepage of peat water. This is important as a severe deterioration in the quality of ridge water seeping upward on the river plain may be anticipated in the near future, which will continue for decades or even centuries (Schot, 1991). This forms a threat for low-productivity rich fens. Peat water is mesotrophic and calcium-rich and may therefore ofler an alternative water soure for the conservation or regeneration of low-productivity rich tens.

\section{AT KNOWI HOCHENTS}

Part of the chemical and isotope data were provided by the Free University Amsterdam. J. van der Wal performed the calculation of charge balances. calcite saturation and carbon species concentrations. C.A.J. Appelo and A.W.M. Verkroost choked the manuscript.

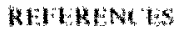

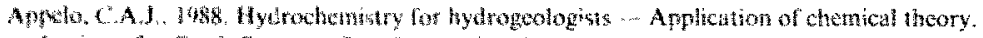

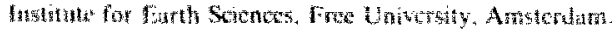


Appelo, C.A.J., Krajenbrink, G.W.J., Rec. C.D.Y. van and Vasak. L., 1982. Beinvloeding van de grondwaterkwatituit in het inflitraticgebied van de noordwestelijke Veluwe. Institurt voor Aariwetenschappen, Vrije Universitcit, Amsterdam.

Belman. B., 1984. The role of water budget studies in environmental planning. Proc. Int. Sen. on Methodology in Lindscape Research and Planning. 15-19 October 1984, Roskilde. Int. Assoc. for Landscape Ecology, pp. 131-135.

Beltman, B. and Grootjans, A.P., 1986. Distribution of nutrient poor plant communities in relation to the groundwater regime and nutrient availability. CHO-TNO, Proc. Inf., 34: 59-79.

Boh, G.H. and Bruggenwert, M.G.M. (Editors), 1978. Soil Chemistry, Part A: Basic elements. Development in Soil Science 5A, Elsevier, Amsterdam.

De Molenaàr, J.G., 1980. Bemestirne, waterhuishouding, intensivering in de landbouw en het natuurlijk milicu. Report 80/6 RIN. Lecrsum.

Eijsink, R., 1991. Grondwaterstroming in Het Gooi en de Vechtstrcek - een modelonderzoek. Studentenverslag Vakgroep Milicukulde Rijksuniversiteit Utrecht/Zuiveringschap Amstel en Gooiland, $37 \mathrm{pp}$.

Gurrels, R.M. and Christ, C.L., 1965. Solstion, Minerals and Equilibria. Harper and Row, New York.

Giller, K.E. and Wheeler, B.D., 1988. Acidifiction and succession in a floodplain mire in the Norfolk Broadland, U.K. J. Ecol., 76: 849-«66.

Grootjans, A.P., Fresco, L.F.M., Everts, F.H., Streekerk, J., Takman, E. and de Vries, N.P.J., 1985. Distribution of marsh plant communities in relation to the regional hydraulic cycle. In: Grootjans 1985, Changes of groundwater regime in wet meadows. Ph.D. Thesis, University of Groningen, pp. 21-45.

Grootjans, A.P.. van Diggelen, R., Wassen, M.J. and Wiersinga, W.A., 1988. The effects of drainage on groundwater quality and plant species dritribution in stream valley meadows. Vegetatio, 75: 37-48.

Holland, H.D., Kirsipu. T.V., Huebner, J.S. and Oxburgh, U.M., 1964. On some aspects of the chemical cvolution of cave water. 3. Geol., 72: 36-6?

Hoogendoorn, J.H., 1983. Hydrochemie Oost-Nederland. Dienst Grondwaterverkenning TNO, Delft-Oosterwolde, $157 \mathrm{pp}$.

Heij, G.J., 1986. Stroming, samenstelling en winning van grondwater in het gebied van de Utrechtse Heuwelrug. RIVM, Leidschendam, $86 \mathrm{pp}$.

Kemmers, R.H., 1986. Calcium as hydrochemical characteristic for cological states. Ekologia (CSSR) 5, 3:271-282.

KNMI and RIVM, 1985. Chemische samenstelling van de neerslag over Nederland. Jaarrapport $1985,144 \mathrm{pp}$.

Koersclman, W. Bakker, S.A. and Blom, M., 1990. Nitrogen, phosphorus and potassium mass balances for two small fens surrounded by heavily fertilized pastures. J. Bcol., 78: 428-442.

Meinardi, C.R.. 1976. Characteristic examples of the natural groundwater compostion in the Netherlands. In: Committe for Hydrological Research-TNO, Verslagen ans Mededelingen, 21: 12 3. 3.

Mook, W.G. 1984. Principles of Isotope Hydrolugy. Institute of Earth Sciences, Free Universily, Amsterdam, $263 \mathrm{pp}$.

Patrick. W.A., 1974. Phosphate release and sorption by soils and sedments: effects of anacrobic conditions. Jeicnce, 186: $53-55$.

Plummer, L.N., Jones, B.F. and Truesdell. A.H., 1976. WATEQF - a FORTRAN IV version 
water following volatilisation of dissolved $\mathrm{CO}_{2}$ as a result of differences in $\mathrm{CO}_{2}$ pressure in surface water and in the atmosphere. $\mathrm{CO}_{2}$ uptake by biological activity is another probable cause of calcite precipitation in surface water.

Summarizing it maly be stated that calcium concentrations in ridge water (type 1) are relatively low. This, is in contrast to what is generally assumed. Shallow peat water (type 3) also has relatively low calcium concentrations which do not differ statistically from ridge water. Higher calcium concentrations are attained in deep peat water (type $3^{*}$ ) and especially in infiltrated surface water (type 2).

It may therefore be concluded that the hypothesis of Hoogendoon is correct, i.e. in the wetlands of the study area, higher final calcium concentrations are attained in groundwater recharged within the wetlands, either by local precipitation or by surface water, than in seepage of groundwater from the adjacent ridge.

\section{DISCUSSION}

In this study, differences in calcium concentration have been examined in different genetic groundwater types in freshwater wetlands on the Ver nt River plain. The validity of the conciusions depend on the applied meth'sd and its assumptions and uncertainties.

The groundwater fow systems and their tracer characteristics are relatively well known. This made it possible to formulate objective hydrological criteria which could be used to distinguish samples according to genetic type. The oxygen-18 isotope especially provided essential information for the distinction of genetic groundwater types. Oxygen-18 analysis should therefore become standard procedure in geohydrological wetland research. The calcium concentration is used as a tracer of groundwater origin by a number of authors in the Netherlands (Van Wirdum, 1980; Beltman, 1984; Grootjans et al., 1985; Kemmers, 1986: Wassen et al., 1989). However, in lis study it has become apparent that the calcium concentration in a groundwater sample generally does not provide a suitable tracer of the origin of the groundwater. Figure 3 indicates that an overlap in calcium concentrations exists between the various genetic groundwater types. Therefore it must be stressed that calcium concentrations alone should not be used as indicator of the recharge area of the sampled groundwater.

The classification scheme atses a combination of criteria, which makes rronecus ctassification unlikely. This is supported by a number of average constituent values calculated for the groundwater types in Table 3. The relatively high tritium concentration observed in type 3 samples confirms recharge by recent precipitation polluted by atomic bomb fallout. This 
indicates recharge of shallow peat water within the wetland, in contrast to recharge by ridge water, which is characterised by low tritium concentrations as a result of a long flow path. Type 2 samples show relatively high chloride concentrations consistent with those in surface water. The difference in chloride concentration between type 2 groundwater and surface water samples points to the trend of increasing salt loads in the Rhine River, whose water is supplied to the wetlands in summer periods. The decrease in sulphate concentrations, observed between surface water and type 2 groundwater and between shallow and deep peat water, points to sulphate reduction. This results from the oxidation of dissolved organic matter, indicating recharge through peat layers.

Average groundwater composition is used for the comparison of genetic types. The use of average values is justified since the parameter distributions of the genetic types are approximately normal. Moreover, to assure the differences observed between the genetic types are significant and real, the probability used in the $t$-test was set at a low level $(P<0.01)$.

The most critical parameter in the calculation of calcite saturation and $\mathrm{CO}_{2}$ pressure is the $\mathrm{pH}$. During sampling of groundwater through air lift or vacuum pumping, volatilisation of dissolved $\mathrm{CO}_{2}$ may occur followed by an increase in $\mathrm{pH}$. In the groundwater sampie $p \mathrm{CO}_{2}$ becomes too low and calcite saturation becomes too high compared with the actual groundwater. This implies that the actual groundwater has an zxtra potential to dissolve calcite which would consequently lead to higher calcite and bicarbonate concentrations. Volatilisation is probably highest in groundwater with a high $p \mathrm{CO}_{2}$ while in open systems more additional calcite can be dissolved. Calcium concentrations would thus increase most in genetic types 2 and 3 which would confirm the main conclusions.

It has been concluded that groundwater recharged locally within a wetland can attain comparable or higher calcium concentrations than groundwater recharged on the ridge. Calcareous groundwater conditions in the root zone of rich fens can therefore be brought about not only by the upward seepage of ridge water but also by the seepage of groundwater recharged in adjacent wetlands.

The recognition of these different origins of calcium-rich a ater is of direct importance for nature conservation strategies. When it is assumed that calcium-rich groundwater sensu stricto is important for low-productivity rich fens then water management should focus on the seepage of groundwater in general, no matter what the origin of the groundwater.

However, calcarcous conditions as stich may not have a direct effect on plant growth, but rather as a conditioning factor for nutrients, $s_{\text {specially }}$ phosphorous. In low-productivity rich fens the availability of phosphorus 


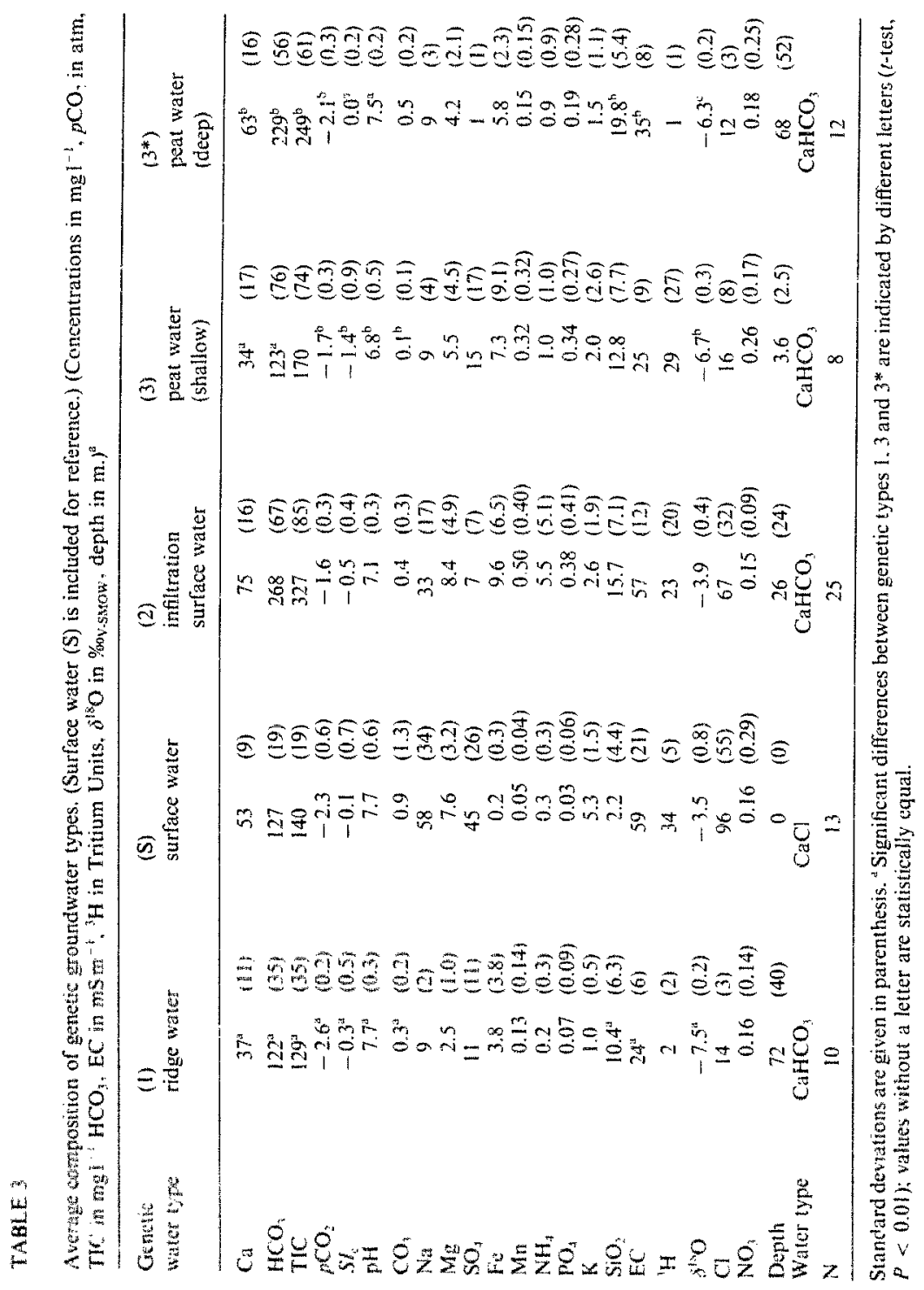




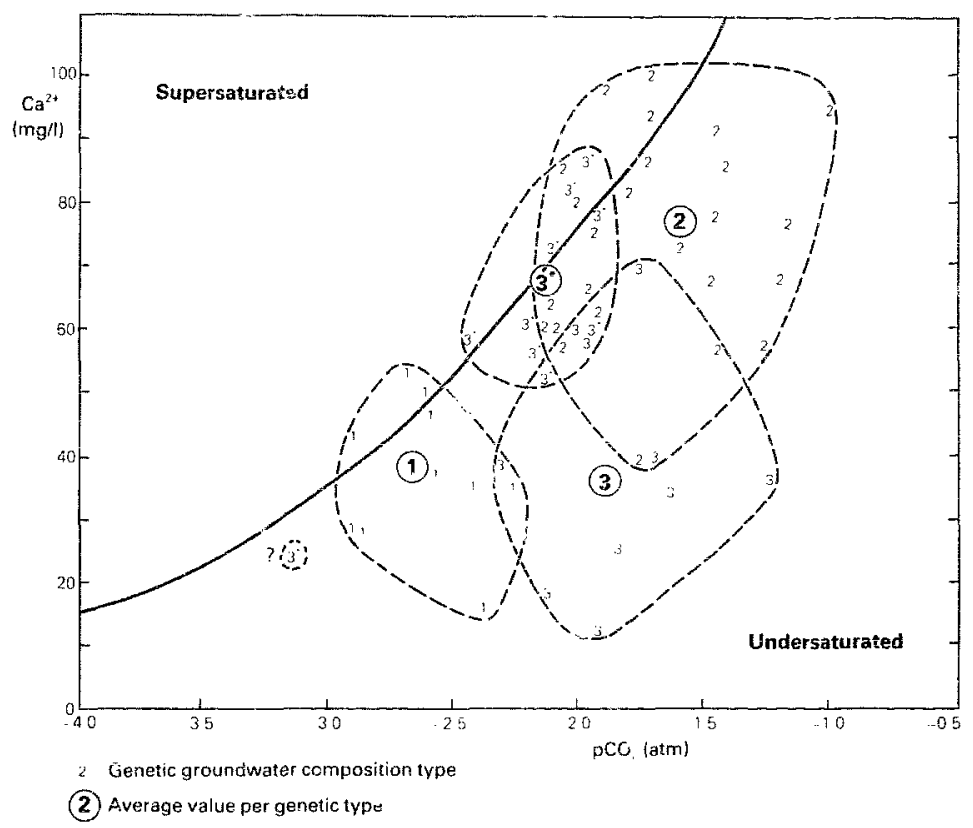

Fig. 3. The relation between $\mathrm{CO}_{2}$ pressure $\left(p \mathrm{CO}_{2}\right)$, calcium concentration and calcile saturation (diagram reproduced with permission from Holland el al.. 1964).

flows through the Pleistocene sand aquifer underlying the wetlands. Calcite is dissolved almost until saturation in deep peat water, indicating that sufficient calcite is present in the sand aquifer. This is consistent with information from borings. The slight trend of decreasing $p \mathrm{CO}_{2}$ from the type 3 Geld to the type $3^{*}$ field in Fig. 3 indicates that dissolution conditions change from open in the peat layers to closed in the sand aquifer, where the water is further from $\mathrm{CO}_{2}$ sources.

The highest calcium concentration in the study area is found for infiltrated surface water (type 2). Together with the high $p \mathrm{CO}_{2}$, this points to open system dissolution. The observed calcium and bicarbonate concentrations and $\mathrm{pH}$ correspond weil to those in Table 1 for open system dissolution with calcite present in the soil zone. Thus, calcite is readily available in sediment on the bottom of lakes and ditches through which surface water percolates during infiltration. This may originate from calcite precipitation in surface 
Becaluse of differences in calcium concentrations, it appeared necessary to consider separately deep type 3 samples not taken in or directly below the peat layer. Deep type 3 samples (greater than $10 \mathrm{~m}$ below ground surface) are hereafter denoted as type $3^{*}$ (deep peat water).

\section{Data on water composition}

Although over 6000 analyses of groundwater and surface water samples arc available, only 228 groundwater and 21 surface water samples have been analysed for oxygen-18. The 228 groundwater analyses have been classified according to genetic type on the basis of the hydrological critera. Analyses which fail to meet the criteria of any of the genetic types (e.g. polluted samples) have been discarded $(N=173)$.

Each analysis includes 15 chemical parameters, an oxygen-18 analysis and often one or more other isotope parameters. In acidition, the following parameters have been calculated: $\mathrm{CO}_{2}$ pressure $\left(p \mathrm{CO}_{2}\right)$, calcite saturation index $\left(\mathrm{SI}_{\mathrm{c}}\right), \mathrm{HCO}_{4}$ and $\mathrm{CO}_{3}$. The calculations were made using the method described by Stuyfzand (1989) which only requires temperature, pH, electrical conductivity, alkalinity and the concentrations of calcium and sulphate as input parameters. Alkalinity is assumed equal to the sum of the $\mathrm{HCO}_{3}$ and $\mathrm{CO}_{3}$ concentrations. Calcium concentrations are corrected for complexation as $\mathrm{CaSO}_{4}^{\circ}$. This method is applicable for: temperatures, $0-90^{\circ} \mathrm{C} ; \mathrm{pH}, 4.35-$ 9.5 ; ionic strength, $0-700 \mathrm{mmol}^{-1}$ or electrical conductivity $0-5200 \mathrm{mSm}^{-1}$ $\left(20^{\circ} \mathrm{C}\right)$ and produces results for calcite saturation with an accuracy comparable with those of speciation models such as WATEQF (Plummer et al., 1976).

The reliability of the data was tested by charge balance calculations. For the 68 analyses used in the calculations, $96 \%$ are withir $5 \%$ deviation from electro-neutraity. Only three analyses show a deviation between 5 and $10 \%$.

\section{Test of the hypothesis of Hougendown}

For eacli genetic lype, the average groundwater composition has been calculated. The average composition of surface water in wetlands on the Vecht River plain has also been calculated for reference. A Student's $t$-test was used to assess whether the true means of chemical or isotope parameters of two different genetic groundwater types are equal on untoul. $i$, whether signiftan diflerences in groundwater composition are present betwees, the genetic types.

For each wated type, the normality of the parameter distributions has been examined by the calculation of the skewness. Moreover. the standard deviation and minimum and maximum values have been examined to check 
whether outliers are significantly afrecting the means. For calcium. hisiograms have also been studied. It was apparent that all the parameters are sufficiently normally distributed to justify the use of a $t$-test.

The first step in the $t$-test procedure (SAS, 1985) was to compute a F'(folded) statistic (Steel and Torrie, 1980) in order to test for equality of the two variances. The $t$-test then calculates a $t$-statistic for equal variances and an approximate $t$-for unequal variances.

The results of the $t$-test with respect to the calcium and $\mathrm{HCO}_{3}$ concentraions enable a conclusion on the validity of the hypothesis of Hoogendoorn. Significant differences between other chemical parameters are related to the observed differences in the calcium and $\mathrm{HCO}_{3}$ concentrations.

\section{RESULTS}

Table 3 shows the average compusition of the genetic groundwater types, while the relation between the calcium concentration, $p \mathrm{CO}_{2}$ and caicite saturation for each genetic groundwater type is shown in Fig. 3. The diagram facilitates interpretation of calcium concentrations in terms of open and closed system dissolution of calcite. For clarity, the following discussion is based on average constituent values for each genetic groundwater type (Table 3).

Ridge water (type 1) shows relatively low calcium and bicarbonate concentrations and $p \mathrm{CO}_{2}$ and a relatively high $\mathrm{pH}$, resembling those in Table 1 for closed system calcite dissolution (soil air $\mathrm{cCO}_{2}$ of $10^{-1.5}$ ). 1 . is implies calcite has been leached from the upper part of the aquifer on the ridge, which is consistent with information from borings. Calcite is only present in deeper parts of the aquifer where is dissolves under closed conditions. Dissolved $\mathrm{CO}_{2}$ is used up daring calcite dissolution and the final calcium concentration is consequently relatively low.

Shallow peat water (type 3) shows calcium and bicarbonate concentrations similar to those of ridge water. $\mathrm{CO}_{2}$ pressure is, howeve ${ }^{*}$, significantly higher in type 3 indicating solution within the $\mathrm{CO}_{2}$-producing soil zone. The strong undersaturation of type 3 groundwater indicates either that disequilibrium conditions occur or that calcite is present only localiy in the wetland peat laycrs. The latter may be caused by (partial) leaching of caicite from the, formerly calcareous, peat layers (Wassen et al., 1989). Undersaturation may then result from the mixing of water which has been in contact with calcite and water which has not been in contact with calcite. With respect to calcite, type 3 water is aggressive (high $\mathrm{CCO}_{2}$. TIC $>\mathrm{HCO}_{3}$ low $\mathrm{pH}$ ) and it has the potential to dissolve additional calcite. This potential is indeed observad during the evolution of type 3 groundwater into type $3^{*}$. The calciam concentration significantly increases as shallow groundwater from peat layers 
poat layers on the river plains (peat water).

The distinction is based on the principal groundwater flow systems ant on the principal ditferences in recharge water source (precipitation vs. surface water) and soil conditions (dry sandy soil vs. wet peat soil) in diflerent recharge areas.

The following objective criteria were used to distinguish between genetic groundwater types:

Sampling location. The groundwater flow systems in the study area indicate that samples from the ridge are recharged by precipitation on the ridge. Samples from the river plains may originate from either the ridge or the river plain (Fig. 2). The sampling location thus provides a first indication of the general soil conditions and possible water sources in the recharge area.

Oxygen-18 concentration. Groundwater $\$ 180$ values in recharge areas of Pleistocene sands in the eastern Netherlands amount to $-7.5 \pm 0.5 \%$ (Mook, 1984). Groundwater samples with $\delta 180$ values higher thatn those observed in groundwater from the upland recharge areas (i.e. greater than $-7.0 \%$ ), indicate that the water has been subjected to increased evaporation compared with that on the ridge. Higner evaporation would occur mainly from surface water and to a lesser degree from the peat and clay layers in the wetlands as fast downward movement is hampered by low hydraulic condactivity. Surface water $\delta 180$ values of wetland lakes in the study area vary from -2.0 to $-4.7 \%$. Peat water $\delta 180$ values are expected to be higher (less negative) than those in ridge water, but lower than those in surface water.

Chloride concentration. The conservative chioride ion can be used as a tracer of various groundwater sources. Groundwater recharged by precipitation will reflect chloride concentration in precipitation times as an evapora. tion concentration factor. The average chloride concentration in precipitation in the study area is about $5 \mathrm{mg}^{-1}$ (KNMI/RIVM, 1985). Since the maximum concentration factor on the ridge is approxinately 4 (Appelo et al, 1982), chloride cencentrations in unpolluted ridge water will not exced $20 \mathrm{mg} /{ }^{\prime}$. The concentration factor in peat water thay be higher than 4 , but is not expestat bexced 6.1 (apen water cvaporation). Chloride concentrations in poit walar are therefore lexs than $31 \mathrm{higl}$ '. Surlace water which is supplied to the polders in summer shows relatively high chloride concentrations due to pollution $\left(\left.\mathrm{Cl} \approx 100 \mathrm{~m} 300 \mathrm{mg}\right|^{-1}\right)$. Groundwater pollution is senerally reflecred by increased chloride concentrations and therefore chloride was used us a criterion lo identify polluted samples. Polluted groundwater my lotul 6 misintertatation of natural gatoudwater composition, e.g. Hrough increased falcium concentantions from fertibzer application.

Nitrate concentraton. Sirte pollution is not always refected by an increase in chloride concentution, nitrate $\left(\mathrm{NO}_{3}\right)$ concentration is used as another criterion to exclude samples affected by pollution. Nitrate concentrations in 
TABLE 2

Criteria for the classification of groundwater samples as genetic groundwater composition types. (Brackish groundwater $\left(300<\mathrm{Cl}<10000 \mathrm{mg}^{-1}\right)$ is left out of consideration.)

\begin{tabular}{|c|c|c|c|c|c|}
\hline \multicolumn{2}{|c|}{ Genetic type } & \multirow{2}{*}{ Lucation } & \multirow{2}{*}{ Oxygen- 18 (\%ovsmow $)$} & \multirow{2}{*}{$\frac{\left.\begin{array}{l}\mathrm{Cl}^{-} \\
(\mathrm{mgl}\end{array}{ }^{1}\right)}{<20}$} & \multirow{2}{*}{$\frac{\mathrm{NO}_{3}}{\left(\mathrm{mgl}^{-1}\right)}$} \\
\hline (1) & Ridge water & & & & \\
\hline (2) & $\begin{array}{l}\text { Infiltrated surface } \\
\text { water }\end{array}$ & Vecht River plain & $\delta^{18} \mathrm{O}>-4.7$ & & \\
\hline (3) & $\begin{array}{l}\text { Peat water } \\
(\text { depth } \leqslant 10 \mathrm{~m})\end{array}$ & River plain & $-7.0<\delta^{14} \mathrm{O}<-6.0$ & $<31$ & $<1$ \\
\hline$\left(3^{*}\right)$ & $\begin{array}{l}\text { Peat water } \\
(\text { depth }>10 \mathrm{~m})\end{array}$ & River plain & $-7.0<\delta^{1:} 0<-6.0$ & $<31$ & $<1$ \\
\hline
\end{tabular}

natural groundwater are generally below $\mid \mathrm{mg}^{-1}$ (Meinardi, 1976; Appelo et al., 1982; STOM, 1983). Higher concentrations may, therefore, point to pollution.

Groundwater samples can be classified according to genetic type on the basis of specific combinations of the above criteria (Table 2).

Type 1 samples (ridge water) have been taken from wells on the ridge (Fig. 1). Their $\delta 180$ value is less than $-7.0 \%$, which is approximately the average upper value observed in recent precipitation. This requirement excludes a number of samples from the ridge with relatively high $\delta 180$ values. These samples may represent old groundwater from a period when oxygen-18 concentration, and possibly also chemical compesition, of precipitation differed from that in recent precipitation. The chloride and nitrate criteria exclude samples of pollued groundwater.

Type 2 samples (infiltrated surface water) have been taken from wells on the Vecht River plain. To ensure that the groundwater sample reflects infiltrated surface water, $\delta 180$ must be larger than the smallest $\delta 180$ value observed in wetland lakes on the Vecht River plain, i.e. greater than $-4.7 \%$.

Type 3 samples (shallow peat water) were taken from wells with screens in, or directly below, peat layers on the Vecht River plain. Becatse of a larger evaporation concentration factor in peat layers, higher $\delta 180$ values may be expected for type 3 samples compared with those of type 1. To exclude possible influences of infiltrated surface water, $\delta 180$ must be significantly lower than that of type 2 samples. Therefore, only samples having $\delta 180$ values between -7.0 and -6.0 are classified as type 3 . Pollution by agricultural activities is excluded through the chloride and nitrate requirements. Since evaporation in peat layers is expected to be less than that of open water, chloride concentration must be less $t h 1 n ? 3 \mathrm{mg}^{-1}$. 
clay deposits is closely related to the fixed surface water levels. Data on the chemical groundwater composition is available from over 6000 groundwater analyses of which over 200 have been analysed for one or more isotope parameters.

Groundwater studies have included finite element aquifer modelling (Witmer, 1986, 1989; Snelting and Groenewoud, 1989; Eijsink, 1991), finite difference modelling of flowlines along vertical sections and subsequent verification with environmental tracers (chloride, oxygen-18 and tritum), mapping of groundwater flow systems and studies on groundwater composition (Schot, 1989, 1990, 1991; Schot and Molenaar, 1992; Schot and Van der Wal, 1992).

Groundwater flow is only considered significant in the first $150-200 \mathrm{~m}$ below present sea level. At that depth a sequence of Early Pleistocene marine clays and silty sands is present which is generally considered to form an aquiclude (Fig. 2). Fluvial sands and gravels were deposited on top of the aquiclude up to some $20 \mathrm{~m}$ below present sea level during the Middle Pleistocene. These deposits now form the main aquifer in the study area. During the Saale ice-age, ice-thrusting of the fluvial sands and gravels created the ridge. In places, the aquifer system is divided in two (Vecht River plain) or three (Eem River plain) aqifers by horizontal fluvial or marine clay layers. These clay layers are absent in the ridge although groundwater modelling studies indicate that tilted clay lenses are likely to be present locally (Witmer, 1989; Schot and Molenaar, 1992).

The aquifer is under water table conditions in the ridge while in the river plains it is semi-confined by overlying Holocene layers of peat and fluvial and marine clay.

Overall groundwater flow is directed from the ridge towards the river plains where groundwater discharges in a seepage zone at the foot of the ridge (Figs. 1 and 2). On the Vecht River plain, the seepage water is transported further as surface water in ditches and lakes to the western part of the polders. There, infiltration occurs under the influence of the lower polder levels to the west. Numerous such local recharge-discharge groundwater systens with groundwater llow from high level to lownlevel polders are present on the Vecht River plain (Schot, 1990; Schot \& Molenaar, 1992). Groundwater withdrawals on the ridge for public drinking-water supply have resulted in decreased seepage to the wetlands at the foot of the ridge. Combined with poider drainage, these withd. $\alpha$ wals have resulted in water deficits in the Vecht plain in summer periods (Witmer, 1989). To maintain high water levels for agriculture, polluted strface water derived fron the Rhine River is supplied to the potaers through canals and ditches.

The main source for groundwater recharge in the study area is precipitation. On the Vecht River plain. surface water constitutes an additional 
recharge source. Concentrations of solutes in both recharge water sources may be increased by evaporation before infiltration. For the ridge concentration, factors in precipitation may vary from 2.5 (Heij, 1986) to 3.8 (Appelo et al., 1982). For open water, an average concentration factor of 6.1 has been calculated (Schot, i989).

Recharge water composition may change as a result of physical, biological and chemical processes during percolation through the soil zone. Soils on the ridge are sandy and dry as the water table is generally below the soil zone. On the river plains, soils are rich in organic matter and/or clay and wet, with the water table in the soil zone close to the surface.

Further changes in water composition may occur during groundwater flow, depending on the geochemical conditions in the aquifer, which consists mainly of unconsolidated calcareous quartz sands and gravels. It is assumed that no significant $\mathrm{CO}_{2}$ production occurs in the aquifer beneath the soil zone. Calcite is present in the main sand aquifer throughout the study area, both on the ridge and on the river plains, which is evident from bore data. On the ridge, however, calcite has been leached from the top $5-20 \mathrm{~m}$ of the aquifer (bore data from the National Geological Survey). The Holocene clay layers on the river plains are also calcareous (Soil Map of the Netherlands). For the peat layers, no data has been found on the presance or absence of calcite. In mixed clay/peat layers, calcite is present at least in the clayey facies. The presence of calcite in peat layers seems likely in areas where peat vegetation developed under the influence of seepage of calcareous groundwater from the main aquifer. Calcite precipitation at the surface of the peat deposits may have resulted from the degassing of dissolved $\mathrm{CO}_{2}$ from the seepage water (Kemmers, 1986). Calcite may have been subsequently leached from peat deposits, if they are presently being replenished by precipitation instead of groundwater from the main aquifer. The depth of lewching will be a function of the amount of calcite present in the peat deposits and the amount, and $\mathrm{pH}$, of the recharge water which percolated through the peat over time.

\section{METHOD}

\section{Classification of genetic groundwater types}

Three main types of groundwater may be discriminated in wetlands in the study area (Fig. 2):

Type 1, groundwater recharged by precipitation on the ridge (ridge water);

Type 2, groundwater recharged by infiltrated surface water in the river plains (infiltrated surface water);

Type 3, groundwater recharged by precipitation which percolated through 


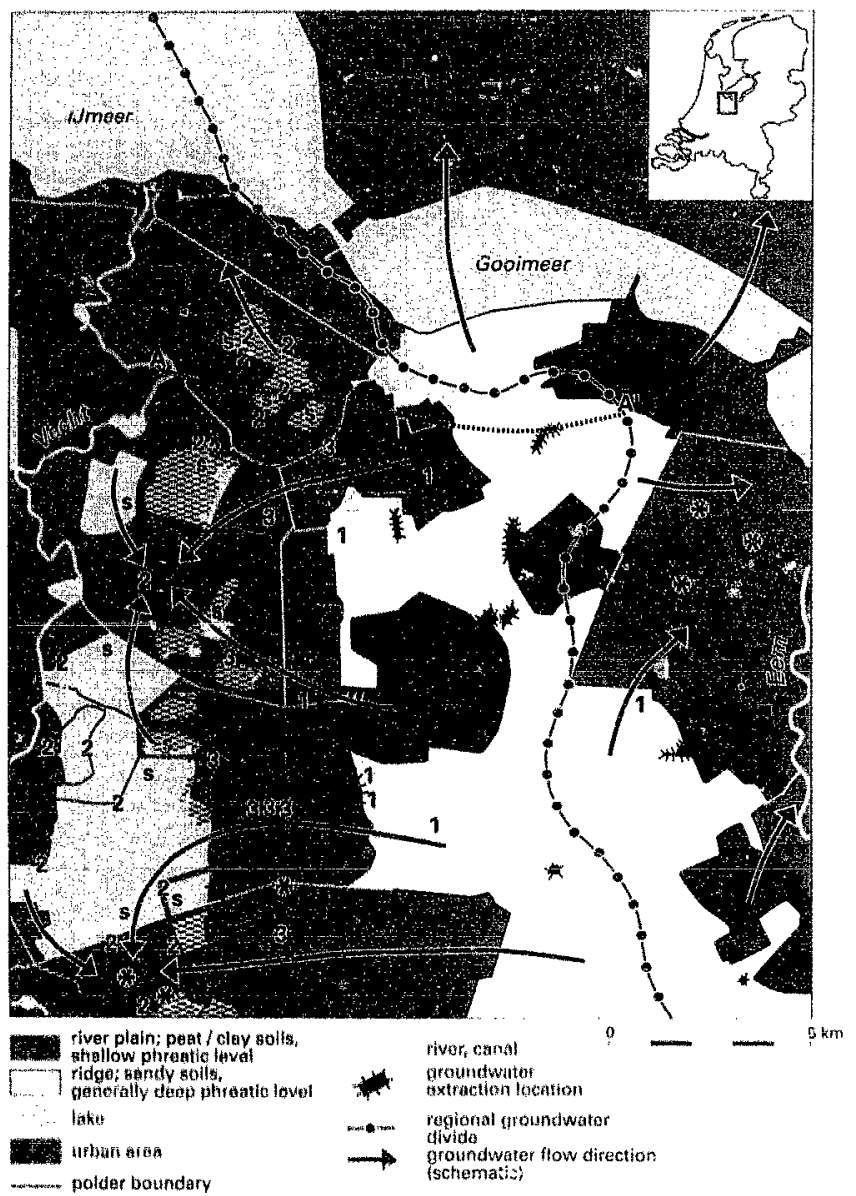

grtwundwater sampling location:

123 genetic type $1,2,3$

* Genetic lyoe $3^{*}$

A.......... Át cross section

* gefietic lype $3^{*}$

Fin- wotand

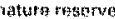

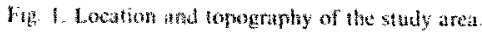




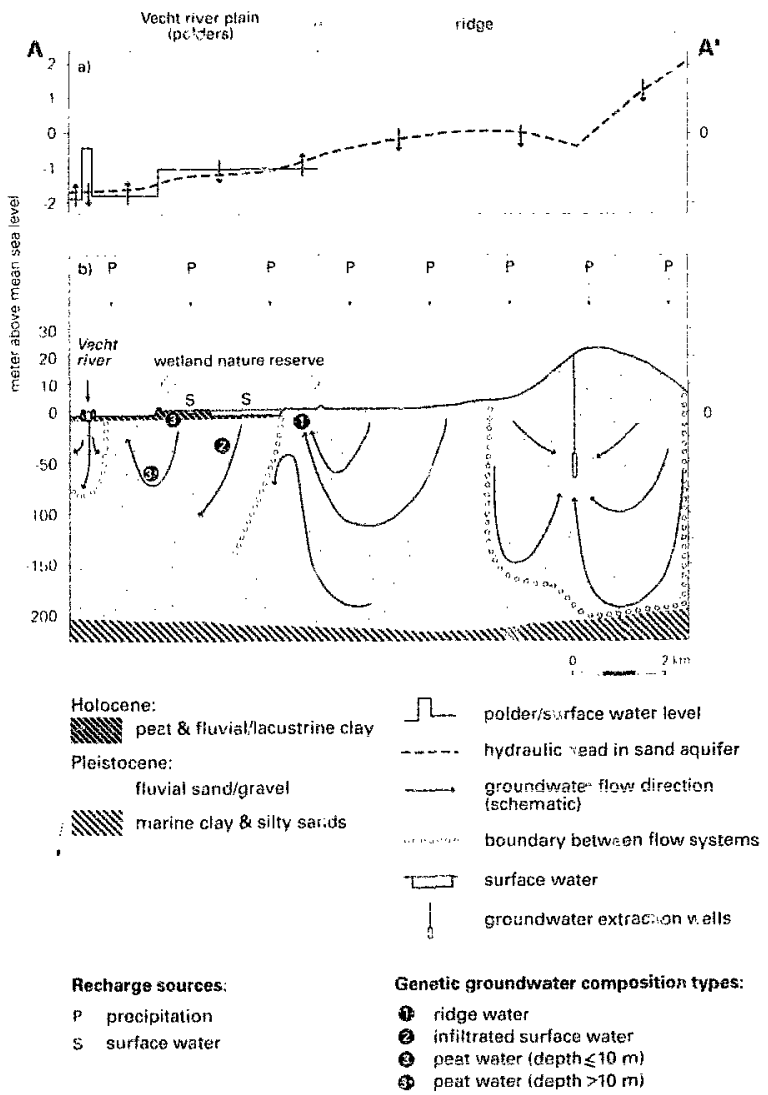

Fig. 2. Geohydrological cross-section $A-A^{\prime}$ (for location see Fig, 1), (a) Vertical gr' rundwater flow direction resulting from differences in polder (surface) water levels and hydraulic heads an the sand aquifer. (b) Genctic groundwater composition iypes in relation to groundwater fow systems.

is therefore relatively well known. Data on hydraulic heads are available from a network of over 100 wells distributed over the area which are measured every fortnight. Additional information on isohypse patterns has been revealed from many local-scale hydrological studies. Surface water levels in the polders, rivers and canals are known as they are kept at fixed summer and winter levels. In the polders, the water taole in the semi-confining peat and 
TABLE 1

Summary of possible concentrations in water in which calcite dissolves until saturation at around $25^{\circ} \mathrm{C}$ (Appelo, 1988)

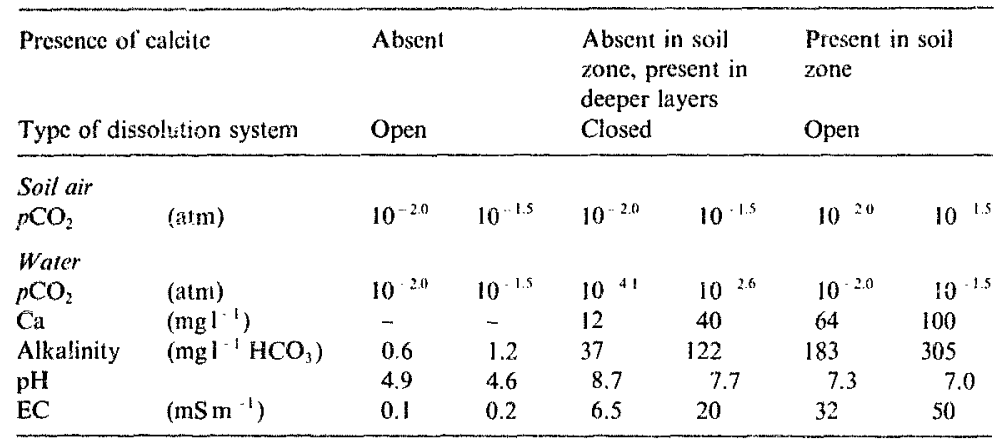

in the wetlands is compared with that of groundwater originating from aii adjacent upland sandy recharge area.

\section{THEORETICAL CONSIDERATION OF CALCITE DISSOLUTION}

Dissolution of calcite is controlled mainly by the $\mathrm{CO}_{2}$ concentration in water which provides the carbonic acid necessary for dissolution (Bolt and Bruggenwert, 1978; Stumm and Morgan, 1981). The partial pressure of $\mathrm{CO}_{2}$ in precipitation is about $10^{-3.5} \mathrm{~atm}$. The $p \mathrm{CO}_{2}$ of soil gas can be considerably higher $\left(10^{-2}-10^{-1.5} \mathrm{~atm}\right)$ due to the production of $\mathrm{CO}_{2}$ through root respiration and bacterial decomposition of organic matter. The dissolution of calcite may be conceptualized under two distinctly different conditions with respect to $\mathrm{CO}_{2}$ (Garrels and Christ, 1965):

(1) Open system dissolution under constant $\mathrm{CO}_{2}$ pressure. This is the case for a calcitebearing soil in which the calcite dissolves until saturation at the fixed $\mathrm{CO}_{2}$ pressurt. The $\mathrm{CO}_{2}$ used during the calcite dissolution is rapidly replenished as a result of the relatively constant $p \mathrm{CO}_{2}$ of soil gas.

(2) Closed system dissolution in which calcite is absent in the soil zone. Recharge water, saturated or nearly saturated with $\mathrm{CO}_{2}$ from the soil zone, is transported downward where it may encounter calcite in deeper layers. In this case, the dissolved $\mathrm{CO}_{2}$ concentration is lowered during the caicite dissolution in the absence of an exterinal source of $\mathrm{CO}_{2}$.

The open system dissolution of calcite leads to higher calcium and $\mathrm{HCO}_{3}$ concentrations in groundwater than the closed system dissolution (Table 1). Open system dissolution is characterized by a near-neutral $\mathrm{pH}$ and a high $\mathrm{CO}_{2}$ 
pressure matching that of soil air. A high pH and low $p \mathrm{CO}_{2}$ (often less than atmosperic $\mathrm{CO}_{2}$ pressure) point to closed system dissolution.

\section{DESCRIPTION OF THE STUDY AREA}

\section{Location, physiography and land use}

The study area is located in the Central Netherlands (Fig. 1). Its main topographic feature is a sandy ridge ranging in elevation from 0 to $30 \mathrm{~m}$ above mean sea level (m.s.l.). To the east and west, the ridge is bordered by the flat-lying Eem and Vecht River plains. The Netherlands have a temperate maritime climate with average temperatures ranging from $2^{\circ} \mathrm{C}$ in January to $17^{\circ} \mathrm{C}$ in July. Mean annual precipitation in the study area is about $750 \mathrm{~mm}$ year ${ }^{-1}$ and the mean annual evaporation is about $500 \mathrm{~mm} \mathrm{year}^{-1}$.

Land use on the ridge consists of urban areas surrounded by woodland, heath and agricultural areas. The naturally marsh: river plains have been increasingly drained for agricultural purposes from the twelfth century onward. Nowadays, the plains are completely divided into polders in which surface water levels, and hence the water table, are artificially controlled and kept at a fixed summer and winter level. Both natural and man-made lakes are present on the Vecht River plain. The man-made lakes are from peat excavation for fucl which ended around 1920 (Van Raam, 1979). At present the river plains are used mainly for dairy farming.

The Vecht River plain also contains a number of wetland nature reserves (Fig. 1). The wetlands are of international importance because of their welldeveloped succession series. The Naardermeer wetland in the north (Figs. 1 and 2) is a Ramsar site. However, over the last few decades, especially low-productivity rich fens have been deteriorating. The management of regional authorities focuses on the protection of these low-productivity rich fens by the conservation of calcareous conditions in the root zone. For this purpose, water management aims at the restoration of the flow of calcareous groundwater towards the river plain by decreasing the amount of groundwater extracted for public and industrial water supplies on the ridge (Provinciaal Bestuur van Noord-Holland, 1986).

Allowing for local differences in the geohydrology, the study area may be considered to be represe rative of other lowland areas in the Netherlands where low-productivity ricl. is are found.

\section{Hydrogeologic and hydrechemical setting}

Groundwater hydrology in the study area has been studied extensively and 
forms a threat to low-productivity rich fens. Peat water may offer an alternative water soure for the conservation or regeneration of low-productivity rich fens.

\section{INTRODUCTION}

The species composition of the freshwater wetland vegetation of Western European lowlands has changed considerably over the past decades (De Molenaar, 1980; Van den Berg and De Smidt, 1985). Low-productivity rich fen vegetation communities have declined and have been replaced by highproductivity rich fen vegetation in some localities and poor fen and even bog vegetation in other localities (Succow, 1988; Giller and Wheeler, 1988; Verhoeven et al., 1988a; Wassen et al., 1990).

Low-productivity rich fens have a characteristic species-rich vegetation of low sedges, herbs and brown mosses. During the development to high-productivity rich fens a shift occurs to a species-poor vegetation of tall sedges, grasses and herbs. Poor fens have a low productivity, but compared with low-productivity rich fens they are less species-rich and Sphagnum species are present in the moss layer. Bogs are very species-poor and have a moss layer dominated by Sphagnum and Polytrichum (Westhoff and Den Held, 1969; Wheeler, $1980 \mathrm{a}, \mathrm{b}, \mathrm{c})$.

The transition of low-productivity rich fens to high-productivity rich fens results from increased nutrient availability, which may be caused by the drainage and subsequent mineralization of the peat (Succow, 1988), or by eutrophication resulting from the inflow of polluted groundwater or surface water (Verhoeven et al., 1988a; Roelofs, 1989). The transition of low-productivity rich fens to poor fens or bogs is partly a natural process (autogenic succession). This may result from continuous peat growth which raises the peat surface to such an extent that water supply in the root zone changes from upwelling groundwater to infiltration of local precipitation. In many cases this sticession is accelerated by human interferences, e.g. by drainage (allogenic succession; e.g. Succow, 1988; Wassen et al., 1989).

The replacement of low-productivity rich fens by either high-productivity rich fens, poor fens or bogs, leads to a less species-rich vegetation type and a loss of biological diversity. The nature conservation policy in the Netherlands therefore aims at the conservation of low-productivity rich fens.

Groundwaters in rich fens have significantly higher calcium and bicarbonate concentrations and higher pH s than poor fens and bogs. These abiotic constituents are considered important conditioning factors for the vegetation of rich fens (Waughman, 1980; Kemmers, 1986). Knowledge on how calcareous groundwater conditions in the root zone come about are therefore 
of direct importance for the nature management strategies aimed at the preservation of biological diversity in low-productivity rich fens.

Lowland werlands in the Netherlanós are often fed by seepage from adjacent upland sandy recharge areas. This seepage water is calcareous as a result of the dissolution of calcite from the sandy sediment matrix during flow towards the low-lying river valleys. Calcareous conditions in the root zone in lowland wetlands in the Netherlands are therefore generally attributed to the discharge of groundwater from adjacent upland sandy recharge areas (Van Wirdum, 1980; Beitman, 1984; Grootjans et al., 1985; Kemrners, 1986; Wasseri et al., 1989). Groundwater origin is thus inferred from calcium and bicarbonate concentrations. Over the past decades this type of groundwater seepage has decreased as a result of an increased extraction of groundwater from the upland recharge areas for public and industrial water supplies. The decline of low-productivity rich fens in lowland wetlands in the Netherlands has therefore been linked to the decreased seepage of calcium-rich groundwater (e.g. Beltman and Grootjans, 1986; Grootjans et al., 1988; Wassen et al., 1990a).

It is, however, not clear if the caicareous conditions in groundwater in lowland freshwater wetlands originate only from groundwater seepage from upland recharge areas. Hoogendoorn (i983) noticed that shallow groundwater in upland sandy recharge areas in the Eastern Netherlands is undersaturated with respect to calcite and therefore concluded that calcite has been leached from the upper part of the aquifer. He calculated the maximum possible calcium concentration if the groundwater, unsaturated with respect to calcite, would dissolve calcite to saturation in the deeper, unleached part of the aquifer. The calculated calcium concentrations appeared to be significantly lower than those observed in the shallow groundwater of the adjacent lowland. Hoogendoorn suggested a local origin for the groundwater in the lowland wetlands rather than seepage from the upland recharge areas. The higher calcium concentrations were supposedly derived from dissolution of calcite in a biologically active, hydromorphic soil zone

Hydrochemical calculations based on the open and closed system theory of calcite dissolution show that the highest calcium concentrations are indeed to be expected in water which has infiltrated locally through a calcite-containing soil (e.g. Appelo, 1988).

In this study, the hypothesis of Hoogendoorn is tested, which assumes a local recharge source for fresh groundwater with a high calcium concentration in Dutch lowland wetlands. For this purpose, first an objective assessment is made of the origin of groundwater present in wetlands on the Vecht River plain in the Central Netherlands on the basis of hydraulic and environmental tracer data. Next, the chemical composition of groundwater recharged locally 
of WATE, a computer program for calculating chemical cquilibrium of natural waters. U.S. Geol. Surv. Water Resour. Inv. 76913), 61 pp.

Provincianl Bestatar van Noord-Holland, 1986 . Provincialal grondwater plan van NoodHolland. Hairlom.

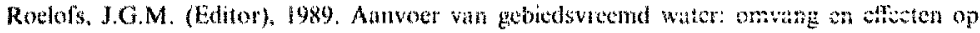
ecosystemen. ['toe. Symp. University ol Ningegen, 21 December 1988, Dept. of Aquatic Ecology and Biogeology, Nijmegen.

Statistical Analysis Systens Instilute, 1985. SAS User`s Guide: Statistics. 5 th Edn. SAS Institutc, Cary. $\mathrm{NC}, 956 \mathrm{pp}$.

Schot, P.P., 1989. Grondwatersystemen en grondwaterkwaliteit in het Gooi en Randgebieden. Report Dept. of Environmental Studies, University of Utrecht, $44 \mathrm{pp}$.

Schot. P.P. 1990. Groundwater systems and analysis of the Natardermeer wetland, the Netherlands. In: E.S. Simpson, and J.M. Shapp (Editors), Selected papers from the 28 th Int. Geol. Congr. Washington, 1989. Hannover: IAH Solected papers on Hydrogeology. Vol, 1, pp. $257 \ldots 269$.

Schot, P.P., 1991. Solute transport by groundwater flow to wetland cosystems. Ph.D.Thesis, University of Utrecht, $134 \mathrm{pp}$.

Schot. P.P. and van der Wal. J., 1992. Human impace wn regional groundwater composition through intervention in natural now pattens and change in landuse. J. Hydrol., 134: 297-313.

Schol, P.P. and Molenaar, A., 1992. Regional changes in groundwater flow pallerns and effects on groundwater composition. J. Hydrol., 130: 151-170.

Snelling $H$. and Groencwoud, P., 1989. Winningsmogelijkheden van grondwater in Het Gooj en Eemgebied. Deelrapport 2: Systemidentificatic. RIVM, rapport no. 728601002, Bilthoven.

Sled, R.G.D. and Torrie, J.H., 1980. Principles and Procedures of Statistics. 2 nd edn. MeGraw-Hill, New York.

SJOM, 1983. Lange termijn oniwikkelingen van vedselarme milieus en grondwater van de pleistocene zandgronden, een verkenning van de periode 1900-2025. Rijksunwersiteit Utrecht, $289 \mathrm{pp}$.

Stumm, W. and Morgan, J.J., 1981. Aquatic Chemistry, 2 nd edn., Wiley, New York, 583 pr

Stuyfzand, P.J, 1989. An accurate, rehtively simpla calcalation of the saturation index for aleite for fresh water to salt water. J. Hydrol., 105: 95 107 .

Succow, M. 1988. Lanschaftsökologische Moorkunde. Gebr. Borntraeger, Berlin, Stuttgart.

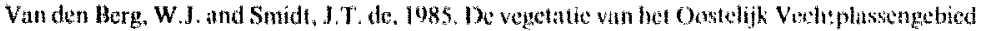

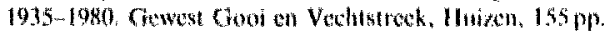

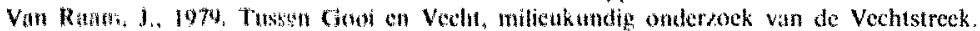

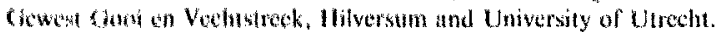

Vin Wirdum, $G_{.,}$1980. Eenvoudige beschrijving van de waterkwaliteitsverandering gedurende de hydrologische krngloop t.b.v. de natuurbescherming. In: J.C. Hooghart (Editor), Watcrkwaliteit in grondwaterstromingstelsels. Rapporten en nota's 5 , Conm. Hydr. Onderzock TNO. Den Hag. pp. $118-143$.

Verhoeven, 3.A, and Arts, H.H.M., 1987. Nutrient dynamics an small mesolrophit: fens

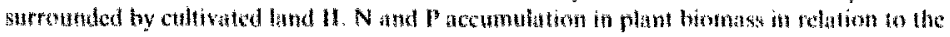

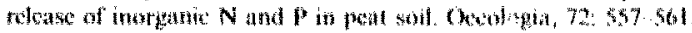

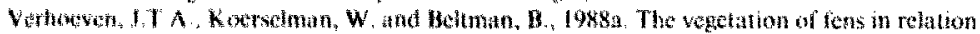
th hair hydrsiogy and natrent aynamics: a case study. In: I.J. Symoens (Editor),

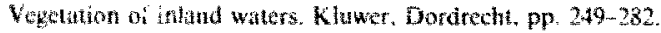


Verhoeven, J.T.A., Kooiman, A.M. and van Wirdum, G., 1988b. Miniralisation of N and $P$ along a trophic gradient in a freshwater mirc. Biogeochemistry, $6 ; 31-43$.

Wassen, M.J., Barendregt, A.. Bootsma, M.C. and Schot, P.P., 1989. Groundweter chen istry and vegetation of gradients from rich fen to poor fen in the Naardermeer (The Netherlands). Vegetaio, 79: 117-13?.

Wassen, M.J., Barendregt A., Schot, P.P. and Beltman, B., 1990a. Dependency of local mesotrophic fens on a regional groundwater flow in a poldered river plain in the Netherlands. Landscape Ecol.. 5, 1: 21-38.

Wassen. M.J., Barendregt, A., Palczynski, A., de Smidt, J.T. and de Mars, H., 1990. The relationship between fen vegetation gradients, groundwater fiow and flooding in an undraincd valley mire at Biebrza, Poland. J. Ecol., 78: 1106-1122.

Waughman, G.J., 1980. Chemical apects of the ecology of some South German peatlands. J. Ecol. 68: 1025-1046.

Westhoff, V. and den Heid, A.J. 1969. Plantengemeenschappen in Nederland. Thieme, Zutphen.

Wheeicr, B.D. 1980a. Plant communities of rich-fon systems in England and Wales. I. Introduction, tall sedge and reed communitics. J. Ecol., 68: 365-395.

Wheder. R.D., 1980b. Plant communities of rich-fen systems in England and Wales. II. Communities of calcarcous mires. 3. Ecol., 58: 405-420.

Wheeler, B.D., 1980c. Plant communities of rich-fen systems in England and Wales. III. Fen meadow, fen grassland and fen woodland communities, and contact communities. J. Ecol., 68: $761-788$.

Wilson, K.A. and Fitter. A.H. 1984. The role of phosphorus in vegetational differentiation in a small valley mire. J. Ecol., 72: 463-473.

Witmer, M.C.H, 1986. Maragement of groundwates and surface water resources in the infiltration arca "Hei Gooi" and adjacent wetlands. AHS Publ. No. 156, pp. 535-547.

Witmer, M.C.H., 1989. Integral water management at regronai ievel. An environmentai study of the Gooi and the Vechtstrek. Ph.D. Thesis. University of Utrecht, "s-Gravenhage. 